\title{
DYNAMICS OF ATTACK ACTIONS IN THE MOBBING STRATEGY: THE CASE OF LITHUANIA
}

\section{Pranas ZUKAUSKAS ${ }^{1}$, Jolita VVEINHARDT ${ }^{2}$, Borisas MELNIKAS ${ }^{3}$, Martin GRANČAY ${ }^{4}$}

${ }^{1}$ Department of Management, Faculty of Economics and Management, Vytautas Magnus University, S. Daukanto str. 28, 44246 Kaunas, Lithuania

${ }^{2}$ Institute of Sport Science and Innovations, Lithuanian Sports University, Sporto str. 6, 44221 Kaunas, Lithuania

3 Department of International Economics and Management, Faculty of Business Management, Vilnius Gediminas Technical University, Sauletekio Ave. 11, 10223 Vilnius, Lithuania

${ }^{4}$ Department of International Economic Relations and Economic Diplomacy, Faculty of International Relations, University of Economics in Bratislava, Dolnozemská cesta 1/B, 85235 Bratislava, Slovakia

E-mails:1p.zukauskas@evf.vdu.lt; ${ }^{2}$ jolitaw@gmail.com (correspondingauthor); 3melnikas@vgtu.lt; ${ }^{4}$ martin.grancay@euba.sk

Received 20 February 2015; accepted 30 June 2015

\begin{abstract}
The purpose of this research is to determine the occurrence and prevalence of different mobbing actions used against a victim in the context of Lithuanian organisations, taking into account the type of professional activity.

A questionnaire was created for the purpose of the research. The reliability of the questionnaire is demonstrated using indicators of the methodological quality of characteristics. The research revealed that in mobbing strategies, most bullying behaviour is interrelated and constructs a particular system, which is driven by insulting communication, defamation and isolation.

The results draw the attention of managers of organisations to the nature of unethical communication and the need to protect dignity and reputation of employees and prevent mobbing and bullying.
\end{abstract}

An original instrument was developed and used to interview mobbing and bullying victims.

Keywords: mobbing, harassment, workplace interpersonal relations, unethical behaviour, spheres of professional activity, Lithuania.

JEL Classification: M12, M14, M19. 


\section{Introduction}

Scientific literature as well as practical organisation management attaches a significant importance to interpersonal relations at work, as they have a considerable impact on organisations and individuals. Although people are often identified as the utmost capital of organisations, this asset may be lost by means other than voluntary decision of employees and/or their managers (e.g., evaluating motives, qualifications and value added by employees and managers). The third force - informal and destructive employee associations and clusters headed by informal leaders - affects the relationship between the employee and the employer. Therefore, in recent decades, many research efforts were aimed at understanding the reasons behind formation of destructive clusters that exist among employees of an organisation, their methods of operation and other circumstances behind the loss of human resources and/or their efficiency. The international scientific community deals with various aspects of this problem, for example, social ostracism in the workplace (Robinson et al. 2013), employee emotional abuse (LutgenSandvik 2003), incivility (Gedro, Wang 2013), or rejection, bullying, mobbing and other antisocial activities (Zapf, Kuhl 2000; Catanese, Tice 2005; Agervold 2007; etc.). Many of these aspects related to removal of employees from the workplace if they are undesirable to the informal environment are discussed by researchers of mobbing and bullying. These two topics are often used as synonyms or can be addressed separately (Chirila, Constantin 2013). Incivility - also referred to as bullying, emotional abuse or mobbing has increasingly become a problematic issue in today's workplace. It is widely recognised that workplace incivility has a significant negative impact on both individuals and organisations (Gedro, Wang 2013). Organisational mobbing is becoming an important topic for management research (Jacobson et al. 2013) due to the apparent coherence between corporate culture and behaviour of employees, where the organisational culture and in-house climate stipulate the appearance of harassment, abuse and mobbing/ bullying (Vartia 2001; Lutgen-Sandvik 2003; Vveinhardt 2011; Lutgen-Sandvik, Tracy 2012; etc.). Notelears (2010) confirmed conclusions made by other researchers (e.g., Fleming, Harvey 2002; Katrinli et al. 2010; etc.) concerning the causality of bullying in organisations. In his opinion, "particularly high/very high job demands and low job control are associated with being a target of severe bullying" (Notelears 2010: 113). In addition, little willingness to report the violator, lenient discipline sanctions and the absence of proper organisational rules create favourable conditions for workplace mobbing (Horvat, Pagon 2012). According to Shallcross et al. (2010), in cases of mobbing, the behaviours are typically covert with informal networks and friendship loyalties providing effective mechanisms for emotional abuse, including those arising from human resource management practices.

Great significance in investigations is allocated to identifying risk groups, which are exposed to the danger of experiencing harassment and mobbing at a workplace. The study of Yusop et al. (2014) shows that exposure to inappropriate behaviour at work does not differ between grades and types of employment. Drabek and Merecz (2013), who investigated the aspects of mobbing at workplace related to stress, occupational position 
and gender revealed that in the study group, women were more exposed to bullying than men. Women were also more exposed to bullying by colleagues, including actions affecting their image and social relationships. Contrary to the standard conclusions in the scientific literature, the study group revealed that bullying was more often experienced by individuals in management positions. Tonini et al. (2011) state that women are more apt to experience mobbing, though at the same time, "women more easily report work problems, unlike men who, according to old stereotypes, manage family through their work, thus achieving a full satisfaction" (2011: 4). In addition, employees with disabilities and long-term illnesses were more likely to suffer ill-treatment in the workplace and experienced a broader range of ill-treatment (Fevre et al. 2013). Subsequent to investigation of a considerable number of employees in health, educational and social care sectors, Van Heugten (2012) found that in the aftermath of their difficult experiences, most victims considered that they had eventually developed a greater resilience. Respondents indicated that resilience was enhanced when the sense of control over their situation improved and when they received support from witnesses and managers. Based on a survey conducted in the sector of logistics, Yildirim and Uysaloglu (2012) concluded that the analysis of demographic factors and the type of jobs can help us identify groups highly prone to mobbing or bullying and hence preventive actions can be better designed in accordance with particular characteristics and needs of these groups.

Leymann (1993, 1996a) identified and described the activities attributed to mobbing; however, unified definition of bullying is still unavailable as the definition greatly differs from country to country. In some countries, the prevalence of bullying is lower than in others. Some countries have bullying that is largely covert, which, of course, is harder to detect and regulate within an organisation (Jacobson et al. 2013). Báguena et al. (2011) explain that estimates of the prevalence of psychological harassment (mobbing/bullying) in the workplace vary enormously from one country to another. One of the main reasons for this variation is the method of evaluation used to make these estimates. Thus, studies often focus on narrow aspects. Therefore, there is still the lack of more comprehensive knowledge, which could be provided by the research covering different areas of professional activity and relationship of attacking actions used against a victim. The aspect of the methodological approach is particularly important in this investigation as it aims to determine the variations and pervasion of mobbing in the context of the business organisations of Lithuania. Identification of the present extent and the forms of mobbing in organisations will be of great importance for further investigations. Also, it will help managers, as it is relevant and applicable on the level of individuals and organisations.

It should be noted that the scientific community uses different terms when referring to the phenomenon of mobbing. According to Chirila and Constantin (2013), the terms abusive behaviour or emotional abuse, generalised nonsexual workplace harassment, workplace trauma and workplace aggression have been used in the USA to describe hostile behaviours relevant to workplace bullying; German-speaking countries preferred the term mobbing and English-speaking countries preferred the term bullying to describe the same phenomenon. In this article, we prefer the term mobbing; however, when quoting other authors, we stick to the originally used term, which in many cases is bullying. 
In the theoretical sense, the article contributes to broadening of the knowledge about the dynamics of mobbing actions used against a victim and occurrence of mobbing in different professional spheres of activity internationally. In addition, the range of research of mobbing in Lithuania is widened.

The originality of the research is based on two aspects: firstly, in the broad context of different occupational activities; and secondly, demonstrating the aspects of interrelations between destructive actions in the workplace. The research is practicable for organisational management in the diagnostics of mobbing actions in relationships between employees and for the development of prevention systems.

Limitations of the research. The research was carried out only in the context of Lithuanian enterprises. Replication of the efforts in several different countries would make it possible to obtain more accurate and comparable data on occurrence of mobbing in different spheres of professional activity and attack actions used against a victim in the cultural context.

\section{Theoretical review}

Psychological terror or mobbing is connected to hostile, non-ethical communication of one or several individuals directed toward another individual. This behaviour pushes the victim into a long lasting position of despair. Statistically, attacks occur at least "once per week" and last for a long period of "not less than six months" (Leymann 1996a). However, in practice, victims feel bullied after a much shorter time (Einarsen et al. 2011). In other words, mobbing is a form of psychological terror, which can be distinguished by its intensity and duration. Due to its intensity and long duration, it becomes a strong social stressor for any individual (Zapf, Kuhl 2000), and has a considerable negative psychological, physical, social and work-related effect on the victim (Vartia 2001; Duffy, Sperry 2007; 2012). This phenomenon is associated with social ostracism, directed against the colleagues who become unwanted in the workplace (Duffy, Sperry 2007; Cullen et al. 2012).

Mobbing involves individual, group and organisational dynamics (Duffy, Sperry 2012). It is a multidimensional phenomenon, manifesting itself through a wide spectrum of activities in the workplace. The workplace harassment activities can be divided into three categories: verbal, non-verbal and physical (Leymann 1996a; Einarsen 1999; Einarsen et al. 2003; Tracy et al. 2006; Katrinli et al. 2010).

According to Leymann (1996a), impacts of mobbing activities can be classified into five groups: effects on the victims' possibilities to communicate adequately; effects on the victims' possibilities to maintain their social contacts; effects on the victims' possibilities to maintain their personal reputation; effects on the victims' occupational situation, and effects on the victims' physical health, the latter involving unhealthy or dangerous assignments, assault and battery, active sexual harassment. The above-described mobbing activities have been substantiated by research and investigations in various countries (Katrinli et al. 2010; Leon-Perez et al. 2013). However, opinions and attitude still differ within the scientific community. According to Waldron and Kassing, workplace 
aggression can also take the form of sexual harassment (Waldron, Kassing 2011), while Duffy and Sperry (2007) exclude the sexual harassment, claiming that: "Mobbing is the nonsexual harassment of a co-worker by a group of other workers or other members of an organization designed to secure the removal from the organization of the one who is targeted" (2007: 398). Nevertheless, in all researches and investigations of workplace interpersonal relations, mobbing is described as a variety of workplace hostility (Fleming, Harvey 2002; Schindeler 2013).

Meschkutat et al. (2002) investigated the mobbing phenomenon in Germany, and made similar conclusions to those of Leymann (1993, 1996a), adding to the list "rumours and gossiping, inadequate treatment of the work results, constant bullying and offenses, hiding important information, criticism, isolation, etc.” (p. 39). Leon-Perez et al. (2013) conducted a research in Spain. They broadened the list of mobbing activities, supplementing it with behaviours such as ignoring the individual's opinion, gossip, offensive personal remarks, social ignorance/exclusion, repeated reminders of errors, withholding information, sneering down work results or ordering work tasks below competence, unmanageable workload, intimidating behaviour, being shouted at, threats of violence/ aggression, self-labelling (being bullied). Yildirim et al. (2007) made a research in Turkey, which revealed four most frequent groups of mobbing activities: isolation from work, attack on professional status, attack on personality, and direct negative behaviours. In some cases, cyber bullying is identified as a separate group, although this type of bullying is mostly characteristic of investigations that target interpersonal relations among students and pupils (Lee 2009; Roland 2011). However, this target group is also important because negative experiences are further transmitted into their work environment. It can be concluded that the existing variety of mobbing activities, manifested in any of its forms or systems, aims to terrify the targeted individual and to create an exceptionally hostile context at the workplace. Similar actions, which do not fit into the definition of mobbing, should be defined as harassment.

Numerous investigations in the field of mobbing/bullying have been conducted in many countries, looking at different aspects of harassment, abuse and mobbing particular to workplace relationships. Many of them focus on the phenomenon of mobbing in separate spheres of activity, especially in some specific areas, such as education (Lee 2009; Horvat, Pagon 2012; Casimir et al. 2012; etc.), health and social care (Yildirim et al. 2007; Katrinli et al. 2010; Fowler, Davis 2013; etc.). Other areas of professional activities in the public sector, such as librarianship (Hecker 2007), higher education (Faria et al. 2012) etc. are also discussed by some authors. Agervold (2007) found that in the sample of 3024 public sector employees, 4.7 per cent of harassment victims matched the features of mobbing. Nevertheless, studies show that more often there is a focus on individual areas or groups of professional activities, similarly to the studies of private sector organisations, which focus on the layers of organisational issues, the issues of harassment participants, health, etc. (Salin 2001; Hodgins et al. 2010; Bailien et al. 2011; Yildirim, Uysaloglu 2012). Authors distinguish differences particular to an industry (Beale, Hoel 2010), enterprises of various sizes and cultures (Baillien et al. 2011), professional groups, such as logistics (Yildirim, Uysaloglu 2012), etc. 


\section{Methodology}

Based on the analysis of mobbing studies, the base of their instruments and by means of operationalization of concepts, a survey questionnaire was developed to be used in Lithuanian organisations. Authors in other countries (e.g., González de Rivera, Rodríguez-Abuin 2003) often adapt the Inventory of Psychological Terrorisation (LIPT) developed by Leymann (1996a; 1996b), which is the questionnaire based on 45 actions of mobbing, traditionally used in mobbing research. On the other hand, as it has already been pointed out, Leymann divided the actions of mobbing into five categories that other authors have interpreted keeping close to the content. While developing the questionnaire for this research, we aimed to combine previous studies and provide a simpler instrument with adapted items, which would also evaluate the nature of the respondent's professional activity. The adaptation of the items is necessary when translating them into the language of the population, where the research is carried out. Also, it is necessary to consider cultural aspects. Based on the presumptions described above, this research has identified three types of activities and defined their characteristics: workplace niggling; formulating negative opinion and assigning inadequate work tasks; physical condition of the employees and the consequences of mobbing acts. Previous research (Vveinhardt 2011, 2012) allowed us to divide attack acts into seven sub-categories. This opened up a possibility for a more sensitive interpretation of internal relations among the identified sub-categories as well as to determine the dynamics within a mobbing strategy. The research questionnaire was adapted accordingly. The content of the categories and sub-categories is described below.

The category called "workplace niggling" consists of communication and isolation subcategories. Separate steps in this sub-category comprise verbal and non-verbal communication, such as innuendo, threat, trying to "reform" the victim, tongue-lashing, disallowing the target to express oneself, constant criticism, ambiguous glances and gestures. The "isolation" sub-category comprises activities, with the help of which the victim is isolated from colleagues, making her/him socially secluded. In other words, ignoring her/his presence, not communicating and disallowing work colleagues to maintain relations with the target.

The category that involves formulating negative opinion and assigning inadequate work tasks consists of three sub-categories: reputation, miscellaneous, assignments. The "reputation" sub-category consist of distinct steps, describing forms of attacks aiming to diminish self-esteem and formulate negative image of the target by mocking, insulting, making fun (with allusion to being unacceptable) about the way the victim moves or talks, undermining her/his decisions, insulting and manipulating his/her work performance, exaggerating physical handicap or disabilities, questioning mental fitness, etc. Mobbing activities, concentrating on exclusion of the targeted person based on her/his ethnic, social, demographic characteristics, religion, beliefs and values were qualified in a separate sub-category, entitled "miscellaneous" and summarising different factors, which tend to become specific reasons for discrimination. The "assignments" sub-category describes the ways of attacking with the aim of discrediting professional qualifica- 
tions of the target. Here, the acts vary from assigning unrealistic and inappropriate work duties to defiance or depriving the target of tasks.

The category called "physical condition and consequences" has two sub-categories. The "health" sub-category includes acts, targeting the health and physical abuse of the attacked person. These can be determined by crude behaviour, the exertion of physical force, sexual abuse, and obligation to carry out health-threatening work. In the subcategory called "damage", separate phases of testing analyse activities causing harm to the target or the target is put under the circumstances aimed to cause damage. This sub-category exclusively identifies the behaviour of the aggressors; however, the impact on health, career and financial losses of the targeted person is not yet estimated, and is an object of a separate investigation.

Determining the reliability of the methodological and psychometric characteristics of the questionnaire. Firstly, the reliability of the instrument used for the research was evaluated. Table 1 provides the methodological qualitative characteristics of the seven sub-categories, which comprise the three categories above.

The value of Cronbach alpha coefficient in all sub-categories exceeds the eligible margin of 0.7 . It is evident that the dispersion range of the sub-categories varies from $44.13 \%$ to $68.59 \%$, thus indicating the number of the respondents, who approve of the selected factors. The fact that the dispersion is lower than the lowest eligible $10 \%$ margin suggests that the category does not contain items reducing the dispersion. The minimal weighing factor can not be lower than 0.3 . Thus, the occurrence of a value lower than 0.3 should indicate that a mismatching item was detected. The weight of an

Table 1. Methodological qualitative characteristics of the questionnaire subscales

\begin{tabular}{|c|c|c|c|c|c|c|c|c|c|c|}
\hline \multirow{2}{*}{ Subscales } & \multirow{2}{*}{$\frac{\mathscr{E}}{\stackrel{\Xi}{E}}$} & \multirow{2}{*}{ 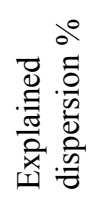 } & \multirow{2}{*}{ 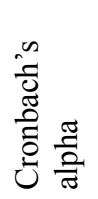 } & \multirow{2}{*}{ 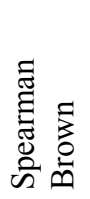 } & \multicolumn{3}{|c|}{ Factorial weight (L) } & \multicolumn{3}{|c|}{$\begin{array}{l}\text { Correlation of } \\
\text { whole unit } \\
\text { (r/itt) }\end{array}$} \\
\hline & & & & & mean & $\min$ & $\max$ & mean & $\min$ & $\max$ \\
\hline \multicolumn{11}{|c|}{ Niggling at workplace relations } \\
\hline Communication & 9 & 44.13 & 0.84 & 0.72 & 0.66 & 0.55 & 0.73 & 0.43 & 0.08 & 0.85 \\
\hline Isolation & 5 & 51.62 & 0.76 & 0.75 & 0.71 & 0.58 & 0.81 & 0.50 & 0.15 & 0.81 \\
\hline
\end{tabular}

Formulating negative opinion and assigning inadequate work tasks

\begin{tabular}{lcccccccccc}
\hline Reputation & 10 & 50.90 & 0.89 & 0.83 & 0.71 & 0.53 & 0.81 & 0.50 & 0.17 & 0.79 \\
\hline Miscellaneous & 4 & 68.59 & 0.76 & - & 0.82 & 0.63 & 0.83 & 0.67 & 0.30 & 0.91 \\
\hline Assignments & 7 & 57.06 & 0.86 & 0.78 & 0.74 & 0.37 & 0.86 & 0.54 & 0.02 & 0.83 \\
\hline
\end{tabular}

Physical condition of the employees and consequences

\begin{tabular}{lllllllllll}
\hline Health & 5 & 48.28 & 0.71 & 0.63 & 0.67 & 0.34 & 0.84 & 0.44 & 0.12 & 0.71 \\
\hline Damage & 3 & 55.91 & 0.61 & - & 0.75 & 0.72 & 0.76 & 0.53 & 0.32 & 0.88 \\
\hline
\end{tabular}


item indicates its equivalence to the category, i.e. it is regarded more significant. The analysis of the meanings of the minimal factorial weight shows that the factorial weights meet the quality requirements of the questionnaire: the meaning ranges from 0.34 to 0.72. The average of the minimal unit correlation factor can not be lower than 0.2 . Thus, the occurrence of a value lower than 0.2 should indicate that a mismatching item was detected. Such cases were not identified in this research (i.e. the average ranges from 0.43 to 0.67 ) (Table 1).

Having evaluated the methodological qualitative characteristics of the sub-categories, collateral factorization is expedient. Both, primary and collateral factorization are necessary when the research deals with a large category questionnaire. The method of factor analysis is essential in order to minimize the variables, i.e. to densify them. The subcategories included in the category should be analogous in content and logic. During the primary factorization, the summation of criterion is calculated, while the collateral factorization unites these criteria into categories. Table 2 presents the joint results of the factorization of the sub-categories.

The closer to 1 is the factor weight, the more relevant is the individual step of the test to the identified factor. The factorization results in investigating harassment and mobbing acts in an organisation indicate that the factor weights in sub-categories range from 0.50 to 0.81 (according to Principal Components method), and from 0.49 to 0.80 (according to Alpha factoring method; this method is more sensitive and, as a rule, the factor weights are naturally lower). The identified factor weights are high, which indicates the credibility of the category, and shows that the questionnaire is appropriate for testing the summation of the evidence. Thus, the calculations show that the instrument is suitable to carry out the research and obtain reliable results.

Table 2. Results of scale and subscale factorization: harassment and mobbing activities in organisations

\begin{tabular}{lllll}
\hline \multirow{2}{*}{ Scales } & \multicolumn{2}{c}{$\begin{array}{c}\text { Principal components } \\
\text { (model of Factor 1) F1 }\end{array}$} & \multicolumn{2}{c}{ Alpha factoring F1 } \\
\cline { 2 - 5 } & \multicolumn{1}{c}{ Subscales } & $\begin{array}{c}\text { Factorial } \\
\text { weights }\end{array}$ & \multicolumn{1}{c}{ Subscales } & $\begin{array}{c}\text { Factorial } \\
\text { weights }\end{array}$ \\
\hline Workplace niggling & Communication & 0.81 & Communication & 0.80 \\
\cline { 2 - 5 } & Isolation & 0.70 & Isolation & 0.67 \\
\hline $\begin{array}{l}\text { Formulating negative } \\
\text { opinion and assigning } \\
\text { inadequate work tasks }\end{array}$ & Reputation & 0.74 & Reputation & 0.65 \\
\cline { 2 - 5 } & Miscellaneous & 0.63 & Miscellaneous & 0.52 \\
\cline { 2 - 5 } $\begin{array}{l}\text { Physical condition } \\
\text { of the employees } \\
\text { and consequences }\end{array}$ & Assignments & 0.71 & Assignments & 0.61 \\
\cline { 2 - 5 } & Health & 0.76 & Health & 0.79 \\
\hline & Damage & 0.50 & Damage & 0.49 \\
\hline
\end{tabular}




\section{Results}

Individuals who experienced harassment or mobbing at their work as well as those searching for information about mobbing in interpersonal relations at the workplace for other reasons and came across the website by Vveinhardt mobingas.lt, became respondents of this research. This stimulated the further individual investigation into this phenomenon. In total, 1174 respondents participated in this research.

The first section of Table 3 lists the respondents by spheres of activity and the frequency of the mobbing experiences. The first data column shows those participants of the survey, who reported having experienced scoff and harassment in the workplace for less than half a year with the frequency of once per week or less. The respondents in the second section of the table suffered harassment and scoff in the workplace for more than six months and no less than once a week. The third section of the table, under the heading "General" presents the results of sporadic cases of harassment and mobbing, experienced by the respondents, which not necessarily grew into systematic mobbing actions (1086 respondents, which makes $92.5 \%$ of the total). The rest of participants did not report either bullying, or mobbing or single cases of harassment experiences, which could be attributed to any group of the analysed actions ( 88 respondents, which makes 7.5 percent). Therefore, their responses were eliminated from the research. Hence, the further analysis is based on the sample of 1086 respondents, i.e. the sampling was aimed specifically at those who have experienced mobbing.

In their intercultural research, Casimir et al. (2012) described a problem, particularly relevant to the phenomenon of mobbing: the acceptance and the level of tolerance of scoffing differed greatly in different cultures. In our investigation, some participants did not report the experience of scoffing in general; however, their answers to separate test steps revealed certain negative actions taken against them. This indicates that not all cases of scoff and harassment are recognised and acknowledged. Consequently, a certain amount of risk exists in most researches that the real category of mobbing in an organisation remains unidentified. Table 3 presents detailed results of the research, classified by spheres of activity.

The data does not follow the Lithuanian Statistical Classification of Economic Activities. However, this way it provides additional information about the victims. The biggest number of mobbing targets is detected in occupations related to services sectors, where jobs involving active communication with clients prevail. Mobbing activities are more frequent in occupations related to administration, services, public management, state defence, trade and wholesale, social care, education and social work.

Table 4 presents internal correlation between harassment and mobbing in an organisation.

The internal correlation reflects the coherence between sub-categories, presenting the answers to individual steps of the test. A statistically significant correlation has been determined between all seven sub-categories, irrespective of their strength. The most prominent correlation was distinguished between "communication"-"reputation" $(0.668)$ and "reputation"-“tasks" $(0.746)$. The ratings indicate to a very strong and sta- 
Table 3. Classification of harassment and mobbing targets by spheres of activity

\begin{tabular}{|c|c|c|c|c|c|c|}
\hline \multirow{2}{*}{ Spheres of activity } & \multicolumn{2}{|c|}{$\begin{array}{l}\text { Have experienced } \\
\text { mobbing }\end{array}$} & \multicolumn{2}{|c|}{$\begin{array}{c}\text { Have experienced } \\
\text { mobbing }\end{array}$} & \multicolumn{2}{|c|}{ Total } \\
\hline & $\begin{array}{l}\text { Frequen- } \\
\text { cies }\end{array}$ & Percent & $\begin{array}{l}\text { Frequen- } \\
\text { cies }\end{array}$ & Percent & $\begin{array}{l}\text { Frequen- } \\
\text { cies }\end{array}$ & Percent \\
\hline Full set of samples & \multicolumn{6}{|c|}{$\mathrm{N}=1086$} \\
\hline Number of spheres of activity & \multicolumn{6}{|c|}{22} \\
\hline Agriculture & 0 & $0 \%$ & 6 & $1.1 \%$ & 18 & $1.7 \%$ \\
\hline Forestry & 1 & $1.0 \%$ & 4 & $0.7 \%$ & 5 & $0.5 \%$ \\
\hline Manufacturing & 2 & $2.0 \%$ & 18 & $3.2 \%$ & 24 & $2.2 \%$ \\
\hline $\begin{array}{l}\text { Electricity, gas, steam supply } \\
\text { and air conditioning }\end{array}$ & 0 & $0 \%$ & 7 & $1.3 \%$ & 10 & $0.9 \%$ \\
\hline $\begin{array}{l}\text { Water supply, sewerage, } \\
\text { waste management and } \\
\text { remediation activities }\end{array}$ & 2 & $2.0 \%$ & 4 & $0.7 \%$ & 6 & $0.6 \%$ \\
\hline Construction & 4 & $4.1 \%$ & 14 & $2.5 \%$ & 22 & $2.0 \%$ \\
\hline Wholesale and retail trade & 16 & $16.3 \%$ & 102 & $18.4 \%$ & 226 & $20.8 \%$ \\
\hline $\begin{array}{l}\text { Repair of motor vehicles } \\
\text { and motorcycles }\end{array}$ & 0 & $0 \%$ & 8 & $1.4 \%$ & 8 & $0.7 \%$ \\
\hline Transport and storage & 2 & $2.0 \%$ & 6 & $1.1 \%$ & 10 & $0.9 \%$ \\
\hline Accommodation activities & 0 & $0 \%$ & 7 & $1.3 \%$ & 15 & $1.4 \%$ \\
\hline Food service activities & 2 & $2.0 \%$ & 0 & $0 \%$ & 12 & $1.1 \%$ \\
\hline $\begin{array}{l}\text { Information and } \\
\text { communication }\end{array}$ & 5 & $5.1 \%$ & 6 & $1.1 \%$ & 18 & $1.7 \%$ \\
\hline $\begin{array}{l}\text { Financial and insurance } \\
\text { activities }\end{array}$ & 0 & $0 \%$ & 10 & $1.8 \%$ & 32 & $2.9 \%$ \\
\hline Real estate activities & 0 & $0 \%$ & 5 & $0.9 \%$ & 9 & $0.8 \%$ \\
\hline $\begin{array}{l}\text { Professional, scientific } \\
\text { and technical activities }\end{array}$ & 0 & $0 \%$ & 2 & $0.4 \%$ & 10 & $0.9 \%$ \\
\hline $\begin{array}{l}\text { Administrative and support } \\
\text { service activities }\end{array}$ & 20 & $20.4 \%$ & 150 & $27.1 \%$ & 256 & $23.6 \%$ \\
\hline $\begin{array}{l}\text { Public administration } \\
\text { and defence }\end{array}$ & 18 & $18.4 \%$ & 56 & $10.1 \%$ & 106 & $9.8 \%$ \\
\hline Education & 8 & $8.2 \%$ & 44 & $7.9 \%$ & 92 & $8.5 \%$ \\
\hline $\begin{array}{l}\text { Human health and social } \\
\text { work activities }\end{array}$ & 5 & $5.1 \%$ & 34 & $6.1 \%$ & 56 & $5.2 \%$ \\
\hline $\begin{array}{l}\text { Arts, entertainment and } \\
\text { recreation }\end{array}$ & 6 & $6.1 \%$ & 39 & $7.0 \%$ & 85 & $7.8 \%$ \\
\hline Other service activities & 7 & $7.1 \%$ & 30 & $5.4 \%$ & 62 & $5.7 \%$ \\
\hline $\begin{array}{l}\text { Activities of extraterritorial } \\
\text { organisations and bodies }\end{array}$ & 0 & $0 \%$ & 2 & $0.4 \%$ & 4 & $0.4 \%$ \\
\hline Cumulative total: & 98 & $100 \%$ & 554 & $100 \%$ & 1086 & $100 \%$ \\
\hline
\end{tabular}


Table 4. Internal correlation between harassment and mobbing in organisations

\begin{tabular}{|c|c|c|c|c|c|c|c|}
\hline Subscales & 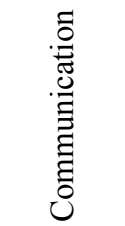 & 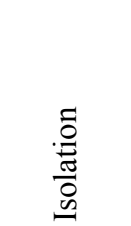 & 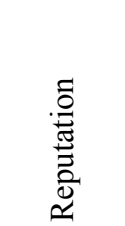 & 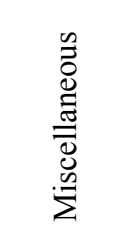 & 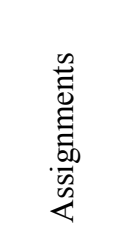 & $\begin{array}{l}\stackrel{\equiv}{ \pm} \\
\stackrel{\mathbb{I}}{\mathbb{I}}\end{array}$ & 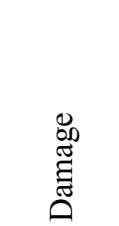 \\
\hline Communication & 1.000 & $\begin{array}{l}0.457^{* *} \\
\text { p } 0.000\end{array}$ & $\begin{array}{l}0.668^{* * *} \\
\text { p } 0.000\end{array}$ & $\begin{array}{l}0.292^{* *} \\
\text { p } 0.000\end{array}$ & $\begin{array}{l}0.606^{* *} \\
\text { p } 0.000\end{array}$ & $\begin{array}{l}0.447^{* *} \\
\text { p } 0.000\end{array}$ & $\begin{array}{l}0.385^{* *} \\
\text { p } 0.000\end{array}$ \\
\hline Isolation & $\begin{array}{l}0.457^{* *} \\
\text { p } 0.000\end{array}$ & 1.000 & $\begin{array}{l}0.330^{* *} \\
\text { p } 0.000\end{array}$ & $\begin{array}{l}0.515^{* *} \\
\text { p } 0.000\end{array}$ & $\begin{array}{l}0.235^{* *} \\
\text { p } 0.000\end{array}$ & $\begin{array}{l}0.590^{* *} \\
\text { p } 0.000\end{array}$ & $\begin{array}{l}0.331^{* *} \\
\text { p } 0.000\end{array}$ \\
\hline Reputation & $\begin{array}{l}0.668^{* *} \\
\text { p } 0.000\end{array}$ & $\begin{array}{l}0.330^{* *} \\
\text { p } 0.000\end{array}$ & 1.000 & $\begin{array}{l}0.296^{* *} \\
\text { p } 0.000\end{array}$ & $\begin{array}{l}0.746^{* * *} \\
\text { p } 0.000\end{array}$ & $\begin{array}{l}0.304^{* *} \\
\text { p } 0.000\end{array}$ & $\begin{array}{l}0.144^{* *} \\
\text { p } 0.000\end{array}$ \\
\hline Miscellaneous & $\begin{array}{c}0.292 * * \\
\text { p } 0.000\end{array}$ & $\begin{array}{l}0.515^{* *} \\
\text { p } 0.000\end{array}$ & $\begin{array}{c}0.296^{* *} \\
\text { p } 0.000\end{array}$ & 1.000 & $\begin{array}{l}0.278^{* *} \\
\text { p } 0.000\end{array}$ & $\begin{array}{l}0.585^{* *} \\
\text { p } 0.000\end{array}$ & $\begin{array}{c}0.143^{* *} \\
\text { p } 0.000\end{array}$ \\
\hline Assignments & $\begin{array}{l}0.606^{* *} \\
\text { p } 0.000\end{array}$ & $\begin{array}{l}0.235^{* *} \\
\text { p } 0.000\end{array}$ & $\begin{array}{l}0.746 * * \\
\text { p } 0.000\end{array}$ & $\begin{array}{l}0.278^{* *} \\
\text { p } 0.000\end{array}$ & 1.000 & $\begin{array}{l}0.346^{* *} \\
\text { p } 0.000\end{array}$ & $\begin{array}{c}0.173^{* *} \\
\text { p } 0.000\end{array}$ \\
\hline Health & $\begin{array}{c}0.447 * * \\
\text { p } 0.000\end{array}$ & $\begin{array}{l}0.590^{* *} \\
\text { p } 0.000\end{array}$ & $\begin{array}{c}0.304^{* *} \\
\text { p } 0.000\end{array}$ & $\begin{array}{l}0.585^{* *} \\
\text { p } 0.000\end{array}$ & $\begin{array}{c}0.346^{* *} \\
\text { p } 0.000\end{array}$ & 1.000 & $\begin{array}{c}0.464^{* *} \\
\text { p } 0.000\end{array}$ \\
\hline Damage & $\begin{array}{l}0.385^{* *} \\
\text { p } 0.000\end{array}$ & $\begin{array}{l}0.331^{* *} \\
\text { p } 0.000\end{array}$ & $\begin{array}{l}0.144 * * \\
\text { p } 0.000\end{array}$ & $\begin{array}{l}0.143 * * \\
\text { p } 0.000\end{array}$ & $\begin{array}{c}0.173 * * \\
\text { p } 0.000\end{array}$ & $\begin{array}{l}0.464 * * \\
\text { p } 0.000\end{array}$ & 1.000 \\
\hline
\end{tabular}

Notes: ** Reliability $0.01 ; *$ Reliability 0.05 ;

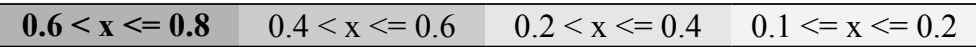

tistically significant internal correlation between "communication" and "isolation", "assignments" and "health", as well as between "isolation", "miscellaneous" and "health". This proves the coherence between various activities of niggling and bullying, which are not sporadic and as a rule form a unique system. The weakest correlation has been detected between "damage" and "reputation" (0.144), "damage" and "miscellaneous" $(0.143)$ and "damage" and "assignments" $(0.173)$. It should be noted that the "damage" sub-category demonstrates considerably weak correlation with other sub-categories, except for one - the "health" sub-category. Activities stipulating material damage or placing the victims into situations to cause such a damage are not as widely spread as other analysed activities.

Table 5 presents the strength of harassment and mobbing activities by spheres of activity. The method of standardisation has been applied to optimally highlight the differences in evaluation. The data were transformed into estimations Z, presuming their negative and positive values. These estimates show a deviation from the rating median. With the help of statistical outliers, Table 5 presents the amplitude of harassment and mobbing activities, where $\mathrm{Z}$ indexes marked dark grey indicate an especially strong and light grey - a relatively weak expression of the value. White colour of $Z$ index means determined yet sporadic mobbing actions. The total confidence interval is 0.12 , i.e. slightly higher than one-tenth of the standard deviation, because the standard deviation 


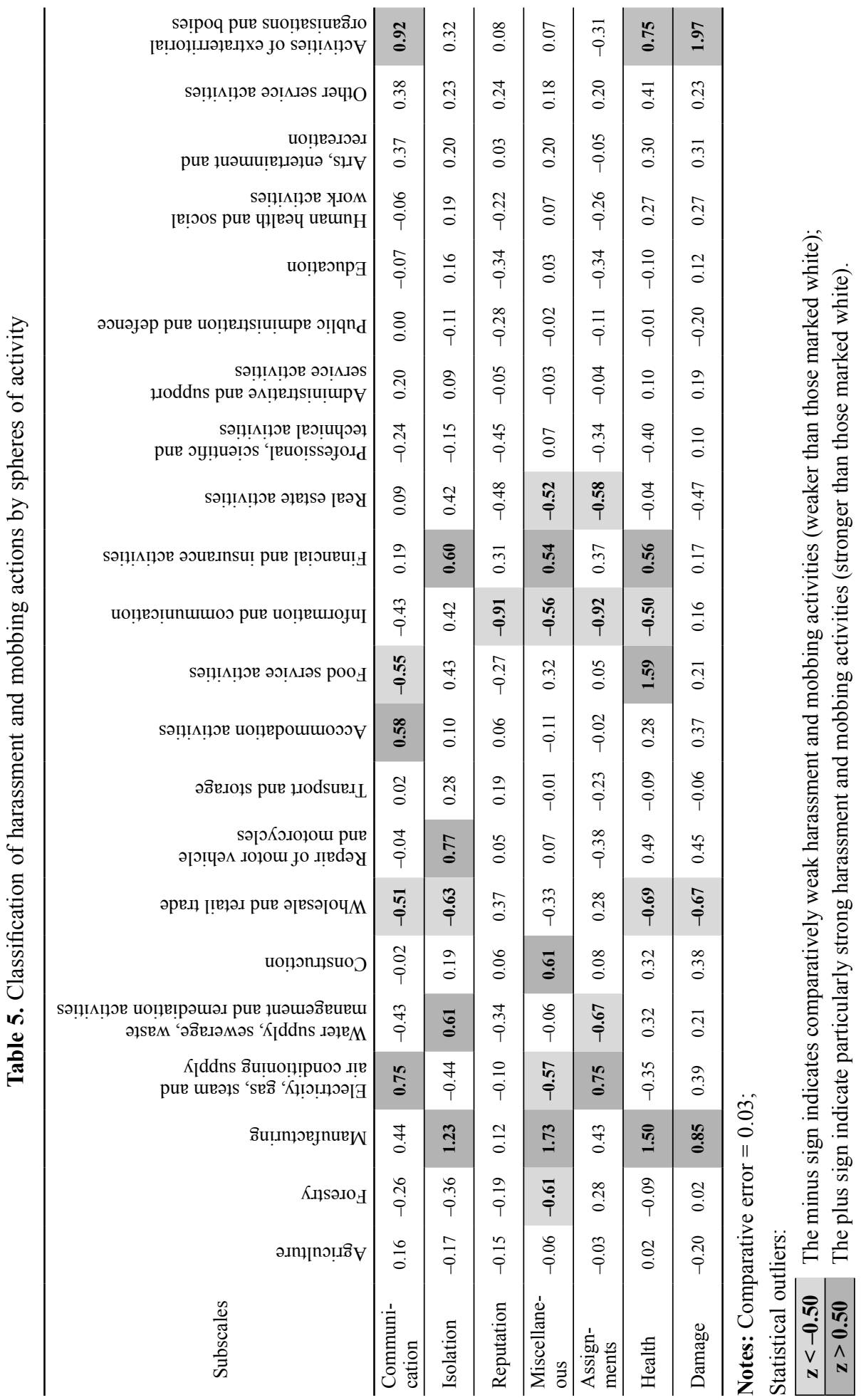


in the $\mathrm{Z}$ scale equals 1 . In this case, half of the confidence interval is 0.06 (variation from -0.06 to +0.06 indicates the centre, where the harassment and mobbing activities are neither specifically strong, nor specifically weak, as they do not exceed the confidence interval). All analysed sub-categories determine nine spheres of activity, where mobbing and harassment is not pronounced (white colour). Taken by sub-categories, communication mobbing is more evident in such spheres of activity as electricity, gas, steam and air conditioning supply, accommodation and activities of extraterritorial organisations and bodies. This type of mobbing actions is less characteristic to wholesale and retail trade and food service activities. Isolation actions are peculiar to manufacturing, water supply, sewerage, waste management and remediation activities as well as to the sphere of activities related to repair of motor vehicles and motorcycles and financial and insurance activities. The estimates of destructive activities, where the reputation of a victim is damaged, do not indicate specific idiosyncrasies, except for information and communication sector, where $Z=-0.91$. In these spheres of activity, other types of mobbing activities, classified under "miscellaneous, assignments and health" subcategories are not pronounced either. There are no spheres of activity where mobbing and harassment would be strongly expressed in all classified sub-categories, except for the "reputation" sub-category, which is typical to all investigated sectors. Regarding the "miscellaneous" category, three spheres of activity are prominent, where this type of attack is strong, these being manufacturing, construction, financial and insurance activities. Overall, manufacturing spheres of activity are peculiar in that they disclose as many as four sub-categories of seven where mobbing is extremely pronounced. They are as follows: "isolation" $(Z=1.23)$, "miscellaneous" $(Z=1.73)$, "health" $(Z=1.50)$ and "damage" $(Z=0.85)$. It should be noted that working professions prevail in this group of spheres of activity. On the other hand, mobbing activities in "isolation", "health" and "miscellaneous" sub-categories are particular to financial and insurance services, which are classified as a group of service spheres.

Having determined specific groups of harassment and mobbing actions and analysed the strength of these actions within these groups, we considered it worthwhile to analyse the data from an additional perspective, i.e. to classify the spheres of activity according to the following constituents: stronger expression of value/weaker expression of value; conditionally stronger actions of harassment and mobbing/conditionally weaker harassment and mobbing actions. For this analysis, we used the Multidimensional Scaling method (MDS), which is defined as a set of methods, widely used for multidimensional data analysis in various fields. According to these methods, in order to maintain the appropriate intervals, similarities and other parameters of relation between the analysed set of objects, the vectors are projected into the space of smaller dimension. The essence of the multidimensional scaling method is placing all variables (i.e. factors) of the research in one space, and further spacing them according to the statistical range between the variables. The variables disperse around two axes, and the four poles of these axes are interpreted and named according to the groups of the variables within these poles. This procedure reveals the internal and often hidden structure of the analysed object (Schiffman et al. 1981; Ferguson et al. 1997; Steyvers 2002; Jaworska, Chupetlovska- 
Anastasova 2009; etc.). MDS is a conjunction of X and Y axis, the so called Cartesian coordinate system, which was used in this research to visualise the strength of harassment and mobbing in 22 spheres of activity from their strongest to weakest expression. The more right position on the $\mathrm{X}$ axis the point occupies, the better are the evaluated characteristics, with the opposite outcome in the $\mathrm{Y}$ axis. Two dimensions - z-score and variation sample - were used in the analysis, while using the MDS model, and a strong emphasis was placed on the dimensions of precedence and the profile of expression (Fig. 1).

The strength of harassment and mobbing actions is classified into five categories: the weakest, weaker than average, average, stronger than average and the strongest. The weakest degree of harassment and mobbing is manifested in "information" and "communication" $(Z=-0.59)$ as well as "wholesale" and "retail trade" $(Z=-0.40)$ spheres of activity. These organisations belong to the services sector. Weaker than average harassment and mobbing manifestation was detected in the following four spheres of activity: real estate activities $(Z=-0.33)$, professional, scientific and technical activities $(Z=$ $-0.29)$, forestry $(Z=-0.24)$, public administration and defence $(Z=-0.15)$. Average manifestation of harassment and mobbing actions comprise the biggest group, consisting of 10 spheres of activity, these being: education $(Z=-0.13)$, water supply, sewerage, waste management and remediation activities $(Z=-0.11)$, agriculture $(Z=-0.09)$,

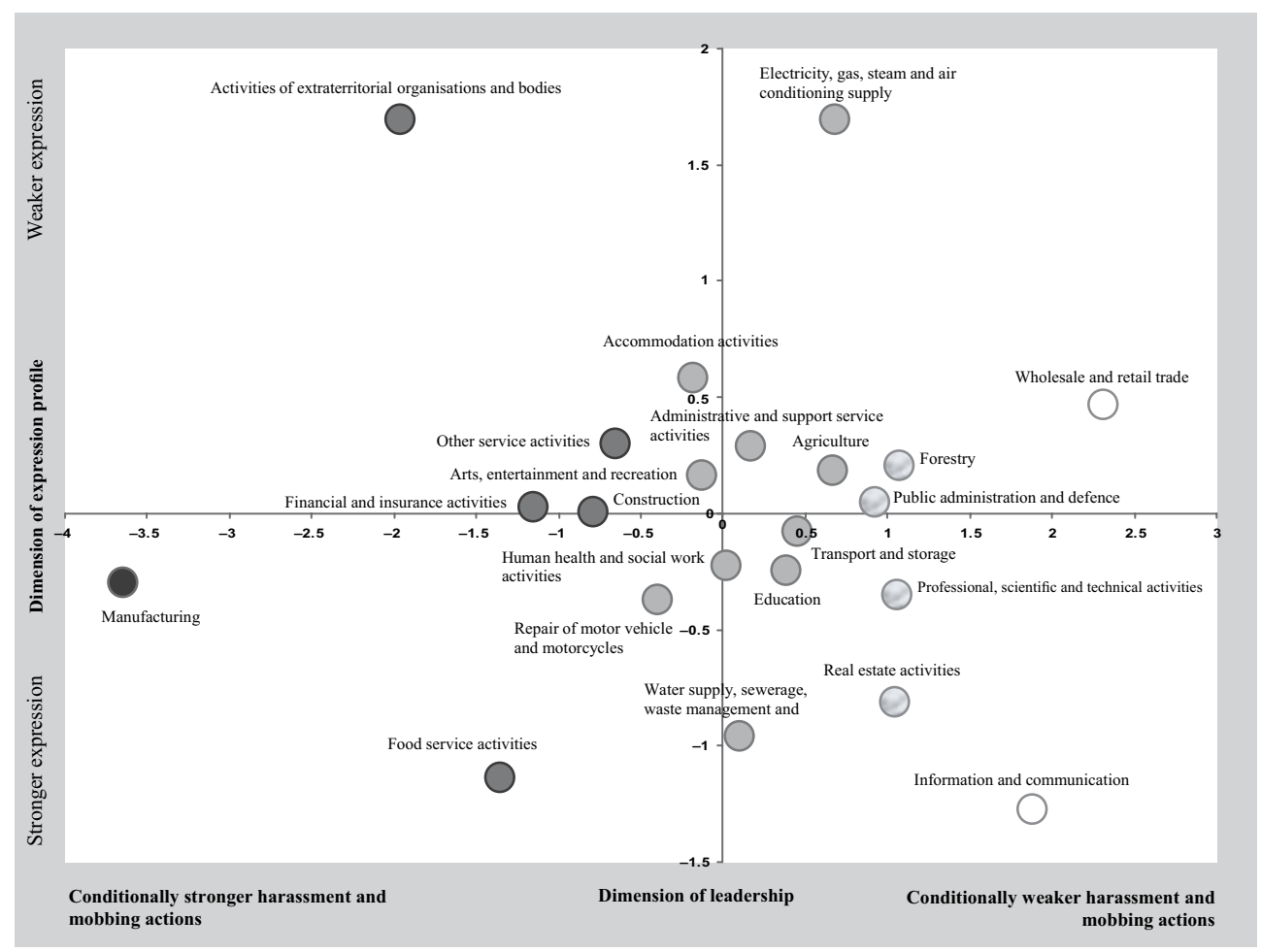

Fig. 1. The strength of harassment and mobbing actions by spheres of activity 
transport and storage $(Z=0.02)$, human health and social work activities $(Z=0.03)$, administrative and support service activities $(Z=0.09)$, electricity, gas, steam and air conditioning supply $(Z=0.12)$, accommodation activities $(Z=0.25)$, repair of motor vehicles and motorcycles $(Z=0.26)$, arts, entertainment and recreation $(Z=0.26)$. However, it is obvious, that the dispersion of the points, indicating the spheres of activity in the Table is irregular. Another five spheres of activity comprise the so-called stronger than average group. They are as follows: food service activities $(Z=0.30)$, construction $(Z=0.32)$, other service activities $(Z=0.37)$, financial and insurance activities $(Z=$ $0.56)$, activities of extraterritorial organisations and bodies $(Z=0.71)$. All spheres of activity in this group, except for construction, are classified as the services sector. Strong expression of harassment and mobbing action has been determined in a single sphere of activity, namely, in manufacturing $(Z=1.24)$.

\section{Conclusions}

This research found the intensity of occurrence of different mobbing actions used against the victim and evaluated relationships between actions of assault and their occurrence, taking into account the type of professional activity. This is a new aspect of the mobbing research. A broader context of research of mobbing and destructive actions not attributed to it can contribute to a deeper and more comprehensive understanding of the phenomenon.

In different countries, the research in the field of mobbing distinguishes between specific mobbing actions; however, there is a considerable gap of knowledge about internal dynamics of such actions, about the type and combinations of non-ethical communication and their correlation. This research aimed to determine the correlation between mobbing actions. Consequently, seven categories (sub-categories) were formed: 1) communication; 2) isolation; 3) reputation; 4) miscellaneous; 5) assignments; 6) health; 7) damage. Statistical reliability of the instruments applied in this research is expressed in high values of the coefficients.

The survey of harassment and mobbing victims disclosed a statistically significant correlation among all seven sub-categories. However, the degree of expression of this correlation varies, which brings us to the conclusion that different modes of attack against the victim are used with different intensity. Consequently, the attack in "communication" and "assignments" sub-categories aim at ruining the victim's reputation and isolation from her/his colleagues. In assessing "the assignments" sub-category, it becomes obvious that it is closely linked to the "health" category. The specification of assignments coincide at large with the above conclusions, stating that mobbing exists in the work environment with high level of conflict between the roles and poor social climate, where negative dynamics of interpersonal relations is endemic. From the perspective of the variety of mobbing actions, the strongest correlation has been detected between "health" and "isolation" sub-categories, where the target often is not subjected to direct communicational attack, but rather suffers from hidden discrimination processes. The highest frequency of attack has been detected in the so-called "white collar" spheres of activity, where intense communication with colleagues and clients dominates. 
The overall conclusion: the scale of this research reveals that the mobbing strategies typically comprise a set of intensively mutually inter-correlated mobbing actions, the most prominent of which are insulting communication attacks aimed at ruining professional reputation and social relations of the victim. Detection of such activities should encourage managers to evaluate the quality of internal communications in order to ensure efficient protection of dignity and reputation of their employees. Cases of abuse in work relations could be avoided by implementation of effective internal assignment and supervision system, alongside with rectification of work roles. From the practical point of view, for heads of organisations the research shows and allows comparing the most sensitive areas of relations between employees in accordance with the nature of the professional activity, which is relevant for prevention of mobbing.

This research extends the literature on studies of mobbing in a number of dimensions. Firstly, it adds to the knowledge on occurrence of mobbing according to different professional activities, the arsenal of actions used in attacking the victim and intensity of combinations of individual actions. Secondly, it allows comparing the occurrence of mobbing, bullying and harassment separately by individual professional groups. Thirdly, although it turned out that mobbing and bullying, which is not attributed to bullying, coexist, when evaluating the aspect of individual spheres of professional activities, it appears that statistically mobbing can be more intense than bullying. In other words, the aim to remove unwanted persons from organisations is a purposeful action, which can not always be linked to the general background of destructive, hostile actions in relations between employees in the organisations. Future studies should specify the presumption of this research that general background of destructive actions exists in organisations, and the opportunity of bullying frees initiators' hands, but the existence of bullying does not necessarily lead to the emergence of mobbing. Therefore, the results of the research encourage the future studies, which would evaluate the conditions of organisational management policy deeper, allowing mobbing situations to occur.

\section{References}

Agervold, M. 2007. Bullying at work: a discussion of definitions and prevalence, based on an empirical study, Scandinavian Journal of Psychology 48(2): 161-172.

http://dx.doi.org/10.1111/j.1467-9450.2007.00585.x

Báguena, M. J.; Beleña, M. Á.; Toldos, M. P.; Martínez, D. 2011. Psychological harassment in the workplace: methods of evaluation and prevalence, The Open Criminology Journal 4(Suppl 2-M7): 102-108.

Baillien, E.; De Cuyper, N.; De Witte, H. 2011. Job autonomy and workload as antecedents of workplace bullying: a two-wave test of Karasek's Job Demand Control Model for targets and perpetrators, Journal of Occupational and Organizational Psychology 84(1): 191-208.

http://dx.doi.org/10.1348/096317910X508371

Beale, D.; Hoel, H. 2010. Workplace bullying, industrial relations and the challenge for management in Britain and Sweden, European Journal of Industrial Relations 16(2): 101-118.

http://dx.doi.org/10.1177/0959680110364826

Casimir, G.; McCormack, D.; Djurkovic, N.; Nsubuga-Kyobe, A. 2012. Psychosomatic model of workplace bullying: Australian and Ugandan schoolteachers, Employee Relations 34(4): 411-428. http://dx.doi.org/10.1108/01425451211236841 
Catanese, K. R.; Tice, D. M. 2005. The effect of rejection on anti-social behaviors: social exclusion produces aggressive behaviors, in K. D. Williams, J. P. Forgas, W. Von Hippel (Eds.). The social outcast: ostracism, social exclusion, rejection, and bullying: 297-306. New York: Psychology Press.

Chirila, T.; Constantin, T. 2013. Understanding workplace bullying phenomenon through its concepts: a literature review, Procedia - Social and Behavioral Sciences 84: 1175-1179.

http://dx.doi.org/10.1016/j.sbspro.2013.06.722

Cullen, K. L.; Fan, J.; Liu, G. 2012. Employee popularity mediates the relationship between political skill and workplace interpersonal mistreatment, Journal of Management 40(6): 1760-1778. http://dx.doi.org/10.1177/0149206311435104

Drabek, M.; Merecz, D. 2013. Job stress, occupational position and gender as factors differentiating workplace bullying experience, Medycyna Pracy 64(3): 283-296.

http://dx.doi.org/10.13075/mp.5893/2013/0024

Duffy, M.; Sperry, L. 2007. Workplace mobbing: individual and family health consequences, The Family Journal 15(4): 398-404. http://dx.doi.org/10.1177/1066480707305069

Duffy, M.; Sperry, L. 2012. Mobbing - causes, consequences, and solutions. New York: Oxford University Press. http://dx.doi.org/10.1093/acprof:oso/9780195380019.001.0001

Einarsen, S. 1999. The nature and causes of bullying at work, Journal of Manpower 20(1/2): 16-27.

Einarsen, S.; Hoel, H.; Zapf, D.; Cooper, C. L. 2011. The concept of bullying and harassment: the European tradition, in S. Einarsen, H. Hoel, D. Zapf, C. L. Cooper (Eds.). Bullying and harassment in the workplace. Taylor \& Francis Group, Boca Raton.

Einarsen, S.; Hoel, H.; Zapf, D.; Cooper, C.L. 2003. The concept of bullying at work, in S. Einersen, H. Hoel, D. Zapf, and C. L. Cooper (Eds.). Bullying and emotional abuse in the workplace: international perspectives in research and practice. London: Taylor \& Francis, 3-30.

Faria, J. R.; Mixon, F. G.; Salter, S. P. 2012. An economic model of workplace mobbing in academe, Economics of Education Review 31(5): 720-726.

http://dx.doi.org/10.1016/j.econedurev.2012.04.004

Ferguson, E.; Kerrin, M.; Patterson, F. 1997. The use of multi-dimensional scaling: a cognitive mapping technique in occupational settings, Journal of Managerial Psychology 12(3): 204-214. http://dx.doi.org/10.1108/02683949710174829

Fevre, R.; Robinson, A.; Lewis, D.; Jones, T. 2013. The ill-treatment of employees with disabilities in British workplaces, Work Employment Society 27(2): 288-307.

http://dx.doi.org/10.1177/0950017012460311

Fleming, P.; Harvey, H. D. 2002. Strategy development in dealing with violence against employees in the workplace, The Journal of the Royal Society for the Promotion of Health 122(4): 226-232. http://dx.doi.org/10.1177/146642400212200409

Fowler, M. D.; Davis, A. J. 2013. Ethical issues occurring within nursing education, Nursing Ethics 20(2): 126-141. http://dx.doi.org/10.1177/0969733012474290

Gedro, J.; Wang, J. 2013. Creating civil and respectful organizations through the scholar-practitioner bridge, Advances in Developing Human Resources 15(3): 284-295.

http://dx.doi.org/10.1177/1523422313488062

González de Rivera, J. L.; Rodríguez-Abuin, M. 2003. Cuestionario de estrategias de acoso psicológico: el LIPT-60 (Leymann Inventory of Psychological Terrorization) en versión española [Questionnaire of Bullying Strategies: LIPT-60 (Leymann Inventory of Psychological Terrorization) the Spanish Version], Psiquis 24(2): 59-66.

Hecker, T. E. 2007. Workplace mobbing: a discussion for librarians, Journal of Academic Librarianship 33(4): 439-445. http://dx.doi.org/10.1016/j.acalib.2007.03.003 
Hodgins, M; Battel-Kirk, B; Asgeirsdottir, A. G. 2010. Building capacity in workplace health promotion: the case of the Healthy Together e-learning Project, Global Health Promotion 17(1): 60-68. http://dx.doi.org/10.1177/1757975909356629

Horvat, B. K.; Pagon, M. 2012. Attitudes toward workplace mobbing in Slovenian research organisations, Organizacija 45(4): 159-173. http://dx.doi.org/10.2478/v10051-012-0018-0

Jacobson, K. J. L.; Hood, J. N.; Van Buren III, H. J. 2013. Workplace bullying across cultures: a research agenda, International Journal of Cross Cultural Management 14(1): 47-65. http://dx.doi.org/10.1177/1470595813494192

Jaworska, N.; Chupetlovska-Anastasova, A. 2009. A review of multidimensional scaling (MDS) and its utility in various psychological domains, Tutorials in Quantitative Methods for Psychology 5(1): 1-10.

Katrinli, A.; Atabay, G.; Gunay, G.; Cangarli, B. G. 2010. Nurses' perceptions of individual and organizational political reasons for horizontal peer bullying, Nursing Ethics 17(5): 614-627. http://dx.doi.org/10.1177/0969733010368748

Lee, Ch-H. 2009. Personal and interpersonal correlates of bullying behaviors among Korean middle school students, Journal of Interpersonal Violence 25(1): 152-176.

http://dx.doi.org/10.1177/0886260508329124

Leon-Perez, J. M.; Notelaers, G.; Arenas, A.; Munduate, L.; Medina, F. J. 2013. Identifying victims of workplace bullying by integrating traditional estimation approaches into a latent class cluster model, Journal of Interpersonal Violence 29(7): 1155-1177.

http://dx.doi.org/10.1177/0886260513506280

Leymann, H. 1993. Mobbing: Psychoterror am Arbeitsplatz und wie man sich dagegen wehren kann [Mobbing: psychological terror at workplace and how to combat it]. Reinbek: Rowohlt Verlag.

Leymann, H. 1996a. The content and development of mobbing at work, European Journal of Work and Organizational Psychology 5: 165-184. http://dx.doi.org/10.1080/13594329608414853

Leymann, H. 1996b. Handanleitung für den LIPT-Fragebogen [Leymann inventory of psychological terror]. Tübingen: DGVT-Verlag.

Lutgen-Sandvik, P. 2003. The communicative cycle of employee emotional abuse: generation and regeneration of workplace mistreatment, Management Communication Quarterly 16(4): 471-501. http://dx.doi.org/10.1177/0893318903251627

Lutgen-Sandvik, P.; Tracy, S. J. 2012. Answering five key questions about workplace bullying: how communication scholarship provides thought leadership for transforming abuse at work, Management Communication Quarterly 26(1): 3-47. http://dx.doi.org/10.1177/0893318911414400

Meschkutat, B.; Stackelbeck, M.; Langenhoff, G. 2002. Der Mobbing-Report - eine Repräsentativstudie für die Bundesrepublik Deutschland [Mobbing report: a representative study in the federal republic of Germany] [online], [cited 4 January 2014]. http://www.baua.de/de/Publikationen/ Forschungsberichte/2002/Fb951.html.

Notelears, G. 2010. Workplace bullying: a risk control perspective: Dissertation for the degree philosophiae doctor (PhD). University of Bergen.

Robinson, S. L.; O’Reilly, J.; Wang, W. 2013. Invisible at work: an integrated model of workplace ostracism, Journal of Management 39(1): 203-231. http://dx.doi.org/10.1177/0149206312466141

Roland, E. 2011. The broken curve: effects of the Norwegian manifesto against bullying, International Journal of Behavioral Development 35(5): 383-388.

http://dx.doi.org/10.1177/0165025411407454 
Salin, D. 2001. Prevalence and forms of bullying among business professionals: a comparison of two different strategies for measuring bullying, European Journal of Work and Organizational Psychology 10(4): 425-441. http://dx.doi.org/10.1080/13594320143000771

Schiffman, S. S.; Reynolds, M. L.; Young, F. W. 1981. Introduction to Multidimensional Scaling. Academic Press, New York.

Schindeler, E. 2013. Workplace violence: extending the boundaries of criminology, Theoretical Criminology 18(3): 371-385. http://dx.doi.org/10.1177/1362480613511980

Shallcross, L.; Ramsay, S.; Barker, M. 2010. A proactive response to the mobbing problem: a guide for HR managers, New Zealand Journal of Human Resource Management 10(1): 27-37.

Steyvers, M. 2002. Multidimensional scaling, in Encyclopedia of cognitive science. UK, London: Nature Publishing Group,

Tonini, S.; Lanfranco, A.; Dellabianca, A.; Lumelli, D.; Giorgi, I.; Mazzacane, F.; Fusi, C.; Scafa, F.; Candura, S. M. 2011. Work-related stress and bullying: gender differences and forensic medicine issues in the diagnostic procedure, Journal of Occupational Medicine and Toxicology 6(29). http://dx.doi.org/10.1186/1745-6673-6-29

Tracy, S. J.; Lutgen-Sandvik, P.; Alberts, J. K. 2006. Nightmares, demons, and slaves: exploring the painful metaphors of workplace bullying, Management Communication Quarterly 20(2): 148-185. http://dx.doi.org/10.1177/0893318906291980

van Heugten, K. 2012. Resilience as an underexplored outcome of workplace bullying, Qualitative Health Research 23(3): 291-301. http://dx.doi.org/10.1177/1049732312468251

Vartia, M. A. L. 2001. Consequences of workplace bullying with respect to the well-being of its targets and the observers of bullying, Scandinavian Journal of Work, Environment \& Health 27(1): 63-69. http://dx.doi.org/10.5271/sjweh.588

Vveinhardt, J. 2011. The structurogram of the mobbing diagnostic model, Transformations in Business and Economics 10, 2A(23A): 317-333.

Vveinhardt, J. 2012. Identification of the reliability of methodological characteristics of quality in the diagnostic instrument for mobbing as discrimination in employee relations on purpose to improve the climate in Lithuanian organisations, Transformations in Business and Economics 11(2): 218-232.

Waldron, V. R.; Kassing, J. W. 2011. Managing risk in communication encounters - strategies for the workplace. SAGE Publications Ltd: London.

Yildirim, D.; Yildirim, A.; Timucin, A. 2007. Mobbing behaviors encountered by nurse teaching staff, Nursing Ethics 14(4): 447-463. http://dx.doi.org/10.1177/0969733007077879

Yildirim, H.; Uysaloglu, B. 2012. Impact of demographic factors on employee's perception of mobbing: a case study from a logistics company, Procedia - Social and Behavioral Sciences 58: 634-644. http://dx.doi.org/10.1016/j.sbspro.2012.09.1041

Yusop, Y. M.; Dempster, M.; Stevenson, C. 2014. Understanding inappropriate behaviour: harassment, bullying and mobbing at work in Malaysia, Procedia - Social and Behavioral Sciences 127: 179-183. http://dx.doi.org/10.1016/j.sbspro.2014.03.236

Zapf, D.; Kuhl, M. 2000. Mobbing am arbeitsplatz: ursachen und auswirkungen [Mobbing at Workplace: Causes and Consequences], in B. Badura, M. Litsch, C. Vetter, Psychische Belastung am Arbeitsplatz, Fehlzeiten-Report 1999. Heidelberg: Springer-Verlag. 
Pranas ZUKAUSKAS is a Professor and Dean at the Faculty of Economics and Management of Vytautas Magnus University. His research activity is focused on international economic relations, international business, international marketing, and human resources management. His publications have appeared in the Journal of Baltic Studies, Journal of Business Economics and Management, Transformations in Business and Economics, Engineering Economics and Problems and Perspectives in Management among others.

Jolita VVEINHARDT is a Chief Researcher in Management and Administration at the Institute of Sports Science and Innovations of Lithuanian Sports University and Associate Professor at the Faculty of Economics and Management of Vytautas Magnus University. Her research activity is focused on mobbing in employee relations, organisational climate, nepotism as a management anomaly, values congruence, human resource management, corporate social responsibility. Her publications have appeared in the Journal of Business Economics and Management, Transformations in Business and Economics, Engineering Economics and Problems and Perspectives in Management among others.

Borisas MELNIKAS is a Professor and Head of the Department of International Economics and Management of Vilnius Gediminas Technical University. His research activity is focused on international economics and management, public and business management, innovations, business culture. His publications have appeared in the Engineering Economics, Transformations in Business and Economics, Technological and Economic Development of Economy and Journal of Business Economics and Management among others.

Martin GRANČAY is assistant professor and Vice-Dean for Development at the Faculty of International Relations of the University of Economics in Bratislava, Slovakia. His research focuses on gravity models of trade, history of the principle of comparative advantage and economics of international civil aviation among other topics. He has participated in numerous research stays abroad and has published articles in journals such as History of Economics Ideas, European Transport Research Review or Panoeconomicus. 